\title{
Agricultural Cooperative Development in Thaibinh Province, Vietnam: Situation and Solutions
}

\author{
Nguyen Cong Tiep, Nguyen Van Song*, Nguyen Tho Quang Anh, Ho Ngoc Cuong, Do Thi Diep, \\ Vuong Thi Khanh Huyen, Nguyen Thi Thuy, Tran Thi Thu Trang, Nguyen Van Tuan\# \\ Vietnam National University of Agriculture (VNUA), Hanoi, Vietnam \\ Email: nctiep@vnua.edu.vn, *nguyensonghua@gmail.com,ntqa249@gmail.com, hongoccuonghn@gmail.com, \\ dtdiep189@gmail.com, vuongthikhanhhuyen@gmail.com, nguyenthithuy5590@gmail.com, tranthutrang1712@gmail.com, \\ Nguyenvantuan1@gmail.com
}

How to cite this paper: Tiep, N. C., Song, N. V., Anh, N. T. Q., Cuong, H. N., Diep, D. T., Huyen, V. T. K., Thuy, N. T., Trang, T. T. T., \& Tuan, N. V. (2020). Agricultural Cooperative Development in Thaibinh Province, Vietnam: Situation and Solutions. Modern Economy, 11, 1376-1400.

https://doi.org/10.4236/me.2020.117098

Received: June 2, 2020

Accepted: July 20, 2020

Published: July 23, 2020

Copyright $\odot 2020$ by author(s) and Scientific Research Publishing Inc. This work is licensed under the Creative Commons Attribution International License (CC BY 4.0).

http://creativecommons.org/licenses/by/4.0/

\begin{abstract}
The paper uses data from 477 respondents in Thai Binh province in Vietnam, including subjects related to the status of agricultural cooperative development in Thai Binh province, Vietnam. On the basis of assessing the development of agricultural cooperatives in terms of quantity and quality in recent years, the paper proposes a number of solutions to develop agricultural cooperatives in Thai Binh in the coming years.
\end{abstract}

\section{Keywords}

Development, Cooperatives, Agricultural Collective, Thai Binh

\section{Introduction}

The main causes of strong economic growth in Vietnam in recent years have been the economic transition from only two main business sectors in agriculture, namely state-owned farms and agricultural cooperatives to more diversify economic activity; and a shift from the centralized economy to a market economy (Song et al., 2020).

Thai Binh is an agricultural province in the Red River Delta, with favorable conditions for the development of large-scale commodity agriculture. Therefore, it is essential to renew and develop collective economic organizations under the current conditions of economic integration. In recent years, collective economic

${ }^{\star}$ Corresponding author.

${ }^{*} \mathrm{PhD}$ Candidate. 
organizations in Thai Binh province have achieved certain results. At present, the whole province has 551 cooperatives, including 329 agricultural cooperatives, 115 non-agricultural cooperatives and 85 people's credit funds. The collective economic organizations have partially met the needs of labourers, production and business households, making positive contributions to local socio-economic development ... However, the reality shows that the majority of a number of collective economic organizations in the province are formal and the operational activities are not diversified and unable to adapt to the new economic context, over $90 \%$ of cooperatives and cooperative groups currently do not pay much attention to the consumption of products for farmers (MARD, 2018). In Thai Binh, agricultural cooperatives play an important role in agricultural production as well as socio-economic development of the province. Agricultural cooperatives have played an important role in providing technical assistance, and supports for service stages as well as capital for production in recent years. However, in the context of market economy development and international integration, it is of importance to evaluate and obtain an overview of the status of organization, management and operation of agricultural cooperatives in Thai Binh province, thereby identifying solutions to develop agricultural cooperatives, contributing to the socio-economic development of Thai Binh province in the coming time.

The objective of this paper is to find solutions to promote the development of agricultural cooperatives in Thai Binh.

\section{Literature Review}

A cooperative is a collective/association founded by individuals and/or legal entities on the basis of mutually beneficial cooperation (Brătulescu, 2017). Agricultural cooperatives in rural areas are formed with the main idea of "cooperation" and an important institution in promoting the synergy of household economy, individual economy and other business entities (Duong, 2015). In official documents, Vietnam has introduced the law on cooperatives with 1996, 2003, and 2012 versions. Currently, the view on cooperatives of Vietnam is recognized in the 2012 Law on Cooperatives, which takes effect in 2013. Accordingly, "A cooperative is a collective economic organization with co-owners and legal entity status, established voluntarily by at least 7 members who cooperate with and assist one another in production, business or job creation activities to meet their common needs on the basis of autonomy, self-responsibility, equality and democracy in management of the cooperative" (Vietnam Assembly, 2012).

Agricultural cooperatives play an important role in the livelihoods of people and communities such as job creation reducing unemployment, economic growth and social development (Dogarawa, 2005). Farmers play an important role in modern agriculture. Despite the existence of many different forms, farmers still act collectively as a cooperative development model. This demonstrates the central role of agricultural cooperatives in the agricultural organiza- 
tion system (Huang \& Liang, 2018; Kogabayev, 2019). Agricultural cooperatives can help small-scale producers increase productivity, economic benefits, and negotiate more with other actors in the supply chain. Cooperatives play an important role in helping households increase productivity by switching to small-scale commercial farming (Kogabayev, 2019). Agricultural cooperatives connect agricultural producers in the form of cooperation and economic cooperation. It creates a collective power and thereby improves production efficiency through the use of each member's advantages. Cooperatives can carry out a number of different types of activities that benefit members and help them achieve these goals (Brătulescu, 2017). Cooperatives support expansion and marketing. Cooperatives also act as a source of capital for members. Members consider the cooperative as a feasible and reliable source of support and services (An \& Culas, 2015; Lacuna-Richman et al., 1993; Nguyen, 2012). Socially, the agricultural cooperative plays an important role in protecting and developing the community, as well as in solving the tensions and challenges that may occur in the community (Dogarawa, 2005; Vieta \& Lionais, 2015). As such, agricultural cooperatives help solve many problems such as economic and social properties, including rural unemployment (Shcherbyna, 2014; Vieta \& Lionais, 2015).

In order to develop cooperatives, all members must clearly recognize the economic and social benefits of participating in cooperatives and helping each other, as opposed to their dependence on external aid (Lacuna-Richman et al., 1993). Benefits must be strengthened when forces work together in a cooperative setting, the interests of members are closely interdependent (Mann, 2018). In addition, service cooperatives need to develop because this is one of the factors promoting the development of agricultural cooperatives (Sedik \& Lerman, 2015). It is also necessary to participate in the input and output market through a contract of employment (An \& Culas, 2015), which increases productivity, production quality and efficiency, and reduces farming costs.

The development of cooperatives in general and agricultural cooperatives in particular in Vietnam has undergone many periods with specific characteristics (Duong, 2015; Nguyen, 2012). Firstly, the period from 1954 to 1959 is the period marked with the start of building a group of exchanging labor, developing cooperatives, household economy gradually narrowed. This was the booming period of cooperative development. Cooperatives become a popular form of economic organization and gradually form an individual economic group and production team. During this period, the role of household economy and private economy was negated. Agricultural cooperatives have been piloted since 1955 with the introduction of the Resolution of the 8th Central Committee Conference (Session II) of August 1955 (Central Executive Committee of Vietnam, 1955). Subsequently, many conferences were held to promote the movement of building agricultural cooperatives in particular and cooperatives in general. The second phase, from 1960 to 1986: From the end of 1960, most farmers in Northern Vietnam participated in the low-level cooperative model. Also, at the beginning 
of this period, the first cooperative charter of Vietnam was issued in 1961 and since then, the development of cooperatives in Vietnam has taken place strongly. By the end of 1986, the total number of agricultural cooperatives in Vietnam was more than 17 thousand, accounting for 23.17\% (Nguyen, 2012). Although there was been a strong growth in number and an important contribution to the national liberation, it had revealed many limitations. The establishment of cooperatives in a way that was forced by the State rather than by the voluntarity of the members. In addition, the autonomy of cooperatives was not respected, given the mechanism of a centrally planned economy (Duong, 2015; Nguyen, 2012; Sultan \& Wolz, 2012). Thirdly, the period from 1987 to 1996 was considered to be a period of strong decline, the number of cooperatives in 1996 was only about half that of 1986 (Nguyen, 2012). Since 1986, Vietnam has introduced an innovation policy by gradually shifting from a centrally planned economy to a socialist-oriented market economy. Accordingly, private economy and individual economy are considered as autonomous economic entities. That has seriously reduced the role and advantages of cooperatives. 1996 was also the year marking the birth of the Law on Cooperatives of the National Assembly of Vietnam (National Assembly of Vietnam, 1996). The period from 1997 to 2002 continued to show the transformation and narrowing in the number of cooperatives. This shows the purification of market economy and integration. The cooperatives that are established not on a voluntary basis and lack of autonomy will face many difficulties and as a result, be eliminated. The period from 2003 up to now marks the recovery of cooperatives, cooperatives are mainly established in rural areas (Nguyen, 2012; Wolz \& Duong, 2010). Two important milestones in this period were the 2003 Law on Cooperatives and the 2012 Law on Cooperatives, which were enacted by the National Assembly of Vietnam (National Assembly of Vietnam, 2003, 2012). The agricultural, forestry and fishery cooperatives accounts for about 50\% of the total (Nguyen, 2012). From 2003 to 2013, Vietnam tested and explored the development of new types of cooperatives in the context of socialist-oriented market economy associated with the implementation of the Law on Cooperatives in 2003; Afterwards, from 2013 to now: Vietnam has been improving the legal framework for new cooperatives (Duong, 2015; Wolz \& Duong, 2010). The new type of cooperative model requires a clear distinction in the interests of members, especially setting membership standards and terminating membership. It can be seen that, at the present stage, Vietnamese cooperatives operate on the principle of voluntary and autonomy. In order to promote the development of cooperatives, Vietnam has issued many legal documents to effectively implement the 2012 Cooperative Law such as Decree No. 193/2013/ND-CP detailing a number of articles of the Law on Cooperatives (Vietnam's Government, 2013), Decree No. 107/2017/ND-CP on amending a number of articles of Decree No. 193/2013/ND-CP (Vietnam's Government, 2017). In addition to legalizing and constantly updating and supplementing, Vietnam also enacts policies to support the promotion of a new type of coopera- 
tive model. Among them is the Decision No. 2261/QD-TTg issued in 2014 approving the cooperative development assistance program for the period of 2015-2020 (Vietnam's Government, 2014). It can be seen that the Vietnamese cooperative has experienced many stages of development and now, the role of the cooperative is undeniable and is gradually developing strongly.

In Vietnam, agricultural cooperatives are a form of collective economy of farmers, so the operation of agricultural cooperatives has great and positive impacts on the production activities of farmer households. The role of cooperatives in agricultural production is reflected in the following aspects: thanks to the fact that the operation of cooperatives, the inputs and service stages for agricultural production are provided in a timely manner, and of great quality, the following production stages are guaranteed, helping to increase the production efficiency of farmer households. Cooperatives are the representative of its members and protect their legal rights. Cooperatives represent members in their distribution activities with other organizations in accordance with legal regulations. Cooperatives are the place to receive governmental assistance to farmers' households, so the cooperative's activities effectively act as a bridge between the state and farmer households in some cases, when there are many organizations participating in providing services for farmer households, cooperative activities helps to forces the subjects to serve the farmers well (National Assembly of Vietnam, 2012).

In Vietnam, agricultural cooperatives are a form of collective economy of farmers, so the operation of agricultural cooperatives has great and positive impacts on the production activities of farmer households. The role of cooperatives in agricultural production is reflected in the following aspects: thanks to the operation of cooperatives, the inputs and service stages for agricultural production are provided in a timely manner and of good quality; in addition, the following production stages are guaranteed to increase the production efficiency of farmer households. Cooperatives represent and protect legal rights for participating members. Cooperatives represent members in the distribution activities of their members with other organizations in accordance with the law. Cooperatives are the place to receive the State's assistance to farmers' households, so the cooperative's activities act as a bridge between the State and farmer households effectively in some cases, when there are many groups. The organization of service activities for farmer households of cooperative activities is a balance that forces the subjects to serve the farmers well (National Assembly of Vietnam, 2012).

\section{Research Methodology}

\section{Research Methodology}

\section{1) Study site selection}

Selection of study sites and locations: The study area is defined as an area of the districts of Thai Binh province. The study sites of this study are 4 districts, including Thai Thuy, Quynh Phu, Kien Xuong, and Vu Thu. From each study site, 2 different communes were selected; then in each commune, good, medium 
and weak agricultural cooperative models were selected. The above mentioned communes have representative cooperative models in agriculture such as cultivation, husbandry, aquaculture and meet the criteria of good, medium and weak cooperatives.

\section{2) Data collection methods}

a) Secondary data collection methods

- Secondary information is collected from various sources such as books, journals, newspapers, reports of different state organizations at different levels, and websites, etc. which are related to the content of the study.

b) Primary data collection methods (Table 1)

Primary data were collected from the following sources:

+ State management officers related to the development of the collective economy and cooperatives include: provincial management officials, district management officials and commune management officials, specifically:

* At provincial level: Leaders and specialiests of the Provincial Department of Agriculture and Rural Development (3 questionnaires); officials of the Subdepartment of Rural Development-Provincial Department of Agriculture and Rural Development (3 questionnaires); Thai Binh Provincial Department of Industry and Trade (2 questionnaires); officials of Thai Binh Cooperative Union (5 questionnaires); Provincial Department of Planning and Investment (2 questionnaires); Provincial Department of Finance (2 questionnaires). Total: 17 questionnaires.

Table 1. Sampling design.

\begin{tabular}{|c|c|c|}
\hline No. & Respondents & Number of samples \\
\hline 1 & Provincial state management officers & 17 \\
\hline 1.1 & Provincial Department of Agriculture and Rural Development & 03 \\
\hline 1.2 & $\begin{array}{l}\text { Sub-department of Rural Development - Provincial Department } \\
\text { of Agriculture and Rural Development }\end{array}$ & 03 \\
\hline 1.3 & Provincial Department of Industry and Trade & 02 \\
\hline 1.4 & Thai Binh Cooperative Alliance & 05 \\
\hline 1.5 & Provincial Department of Planning and Investment & 02 \\
\hline 1.6 & Provincial Department of Finance & 02 \\
\hline 2 & District state management officers & \\
\hline 2.1 & District leaders & 08 \\
\hline 2.2 & District Office of Economics & 08 \\
\hline 2.3 & District Office of Finance and Planning & 08 \\
\hline 2.4 & Other district officers & 08 \\
\hline 3. & Communal state management officers & \\
\hline 3.1 & Commune leaders & 24 \\
\hline 3.2 & Cooperative leaders & 24 \\
\hline 3.3 & Cooperative members & 320 \\
\hline \multirow[t]{2}{*}{3.4} & People participating in cooperation groups & 40 \\
\hline & Total & 477 \\
\hline
\end{tabular}


* At district level: district leaders (4 districts $\times 2$ questionnaires/district $=8$ questionnaires); officials of the District Department of Economics ( 4 districts $\times$ 2 questionnaires/district $=8$ questionnaires); officials of the District Department of Finance - Planning ( 4 districts $\times 2$ questionnaires/district $=8$ questionnaires); officials from other related departments: 8 questionnaires. Total: 32 questionnaires.

* At communal level: communal leaders ( 4 districts $\times 2$ communes/district $\times 3$ questionnaires/commune $=24$ questionnaires $)+$ Cooperative staff: Officials of the Cooperative Management Board and Control Board: Officials of the Cooperative Management Board and Control Board (4 districts $\times 2$ communes/district $\times$ 3 questionnaires/cooperative $=24$ questionnaires $)+$ Cooperative members: Members (4 districts $\times 2$ communes/district $\times 40$ questionnaires/Cooperative $=$ 320 questionnaires) + People participating in cooperative groups: 4 districts $\times 2$ communes/district $\times 5$ questionnaires/commune $=40$ questionnaires.

The questionnaires for each level and each respondent are different from each other.

+ Experts in cooperative development: in-depth interviews with 15 - 20 experts in cooperative development.

Data was collected using non-random sampling methods (results based on the sources presented above), combined with key surveys, thematic surveys and the use of a number of PRA tools such as group discussion, Venn Diagram, Classification Matrix, and Semi-structured interview. The PRA tools were used in group discussion for cooperative members to find out the strengths and weaknesses in the development of cooperatives in Thai Binh province, thereby helping to propose appropriate solutions. Venn diagram (also known as Venn diagram or aggregation diagram) is a diagram that shows all possible logical relationships between cooperative members and the Cooperative Management Board, showing the close relationship and interactions between the co-operative managers and the cooperative members in order to achieve the cooperative development goals. Semi-structured interview is an interview based on a list of questions or topics that need to be addressed, the order and the way to ask questions may depend on the context and characteristics of the interviewees. The Classification matrix chart consists of a two-dimensional matrix of rows and columns through which the intersection is considered to determine the location, nature of the problem and important ideas to solve. In this research, we arranged the interview responses in order of importance and of the issues that the respondents are concerned about. Discovering important ideas by examining the relationships shown in the matrix cells is an effective method to solve problems during this study.

\section{3) Data synthesis, processing and analysis}

Statistical classification: information is categorized and organized according to different criteria according to specific approaches and analysis purposes.

Descriptive statistics: Using some specific methods and tools as follows: The 
general criteria include: absolute numbers, relative numbers, average numbers; and the sequence of numbers fluctuating over time.

Statistical analysis: using the comparative method to compare the level of phenomena by region, by industry and under a number of different conditions; forecasting method is used in order to predict the development trend of the phenomenon in service of building the deployment roadmap.

\section{Results and Discussions}

\subsection{The Development of Agricultural Cooperatives in Thai Binh}

\subsubsection{Activities of Cooperatives in Thai Binh Province}

Among collective economy forms, there are cooperatives and collective groups. However, in the current context in Thai Binh province, there exists only cooperatives. With limited resources as well as limited time, this study focused on evaluating the performance of agricultural service cooperatives.

1) Assets and capitals of agricultural cooperatives

The scale of the total assets has a great influence on the effectiveness of cooperatives activities of and bio-assets accounting for a large proportion, which will lead to a shortage of working capital or otherwise reduce the efficiency or waste of Fixed assets. In contrast, the bio-assets, which are mainly mobile assets, occupy a large proportion in the cooperative's asset structure, which will ensure the financial capacity of the cooperative and the performance of the services will be better.

In general, through the collected data on the assets of the cooperatives (from business results reports of the coopertatives), it can be seen that the average total assets of the surveyed cooperatives in the area are still low (below 2 billion $\mathrm{VND} /$ cooperative).

- Revenues: The average revenue of 1 cooperative is 1308 billion VND; including 12 cooperatives with a revenue of over 3 billion VND, 28 cooperatives with a revenue of 2 to 3 billion VND, 161 cooperatives with a revenue of $1-2$ billion VND, 82 cooperatives with a turnover of from 500 million VND to less than 1 billion VND and 33 cooperatives with a revenue of less than 500 million VND.

- Profit and loss: There are 277 profitable cooperatives out of a total of 316 (accounting for $87.7 \%$ ), and the remaining 39 cooperatives operate without profit (accounting for 12.5\%). The average profit of a cooperative is 67.402 million VND.

- Cooperative capital and fund: The cooperative charter capital is allocated from the value of assets, the capital of the old agricultural cooperative is transferred and the member contributes more capital. Cooperative officials and service providers contribute a responsible capital of between 500,000 VND and 5 million VND. The average business capital percooperative is VND 2.1 billion; the average fund of a cooperative is 279.2 million VND; The average fixed asset is 1.66 billion VND. 
The total number of cooperative management officials in the whole province is 2214 people. In which: among the Cooperative Directors (Chairman of the Board), 33.6\% have university and college degrees, $47.9 \%$ have intermediate degrees, $18.5 \%$ have primary training; Among the Deputy Directors of the cooperatives: $10.6 \%$ have university and college degrees, $50.0 \%$ have intermediate degrees, and $39.4 \%$ have primary training; while among the Cooperative accountants, $42.2 \%$ have university and college degrees, $49.2 \%$ have intermediate degrees, and $8.6 \%$ have primary training.

2) Infrastructure, warehouses and equipment for the production of cooperatives

- Currently, there are 253 cooperatives with headquarters (accounting for 50.1\%). Cooperatives with spacious and modern offices are built with the aid of Japanese Government such as Binh Dinh (Kien Xuong) and An Ninh (Tien Hai) cooperatives; cooperatives with full offices and meeting rooms such as Thuy Son (Thai Thuy) Vu Hoa in Kien Xuong District, Nguyen Am (Vu Thu), Diep Nong (Hung Ha) have cooperatives with only 1 - 2 working rooms arranged together with Communal People's Committee. Most of the headquarters of cooperatives are degraded and have not been repaired for many years. Not many cooperatives have warehouses, shops to introduce and sell materials for agriculture such as Binh Dinh Cooperative. Some pumping stations and canals have not been built, repaired for a long time, greatly affecting the service efficiency of cooperatives.

- Regarding land use rights: Currently, only 12 out of 316 agricultural cooperatives (3.8\%) have been granted land use certificates, 192 cooperatives (60.8\%) have been allocated land as headquarters but have not yet been granted land use certificates, 124 cooperatives (39.2\%) do not have land for headquarters, only have 1 - 2 rooms arranged in the headquarters of the Comunal People's Committee.

Regarding infrastructure: In the 2010-2016 period, the province has hardened $1142 \mathrm{~km}$ of canals of grade 1 (reaching 62\%); constructing and upgrading intra-field roads of $3539 \mathrm{~km}$ (reaching 74\%); Annually, the central budget shall provide subsidies for irrigation of member households through cooperatives with an average amount of VND 160 billion/year, creating favorable conditions for accelerating agricultural mechanization and transport of materials and commodity and ensuring proactive and effective irrigation. The infrastructure is quite complete for rice production. Currently, it has actively irrigated over $90 \%$ of the cultivated rice area. The milling capacity and rice storage in the province are large, synchronous, the milling equipment is quite modern and has high capacity.

Thai Binh has 30 cold storages for potato seed production and agricultural machines for production of cooperative members with the number shown in Table 2:

With the organizational structure, resources and the role of managing production and service provision, product consumption for cooperative members 
Table 2. Agricultural machines of cooperative members in 2019.

\begin{tabular}{|c|c|c|c|c|c|c|c|c|c|}
\hline \multirow{2}{*}{ No. } & \multirow{2}{*}{ District } & \multirow{2}{*}{$\begin{array}{c}\text { Rice land } \\
\text { area } \\
\text { (ha) }\end{array}$} & \multicolumn{3}{|c|}{$\begin{array}{l}\text { Number of currently used machines } \\
\text { (machines) }\end{array}$} & \multicolumn{4}{|c|}{$\begin{array}{l}\text { The number of machines proposed to support for the period } \\
\qquad 2017-2020 \text { (machines) }\end{array}$} \\
\hline & & & Reapers & $\begin{array}{l}\text { Planting } \\
\text { machines }\end{array}$ & $\begin{array}{c}\text { Tillage } \\
\text { machines }\end{array}$ & $\begin{array}{l}\text { Cold storage } \\
\text { warehourse }\end{array}$ & Reapers & $\begin{array}{l}\text { Planting } \\
\text { machines }\end{array}$ & $\begin{array}{l}\text { Cold storage } \\
\text { warehourse }\end{array}$ \\
\hline 1 & Dong Hung & 11,199 & 144 & 19 & 497 & 9 & 120 & 400 & \\
\hline 2 & Thai Thuy & 12,575 & 149 & 20 & 29 & 2 & 100 & 150 & \\
\hline 3 & Tien Hai & 9706 & 111 & 8 & 163 & 8 & 145 & 167 & \\
\hline 4 & Vu Thu & 7445 & 100 & 6 & 130 & 15 & 60 & 150 & \\
\hline 5 & Hung $\mathrm{Ha}$ & 10,148 & 184 & 4 & 115 & 0 & 70 & 30 & \\
\hline 6 & Quynh Phu & 10,536 & 192 & 24 & 360 & 4 & 70 & 103 & \\
\hline 7 & Kien Xuong & 11,057 & 189 & 20 & 430 & 11 & 135 & 51 & \\
\hline \multirow[t]{2}{*}{8} & Province & 1666 & 16 & 3 & 25 & 3 & 24 & 97 & \\
\hline & Total & 74,332 & 1085 & 104 & 1749 & 52 & 724 & 1148 & 60 \\
\hline
\end{tabular}

Source: Compilation from business results reports of the agricultural cooperatives, 2019.

through signing ordering contracts with businesses; At the same time, facing difficulties such as: global climate change, consumption markets, labor shortage, disrespect of product consumption contracts from cooperative members and enterprises, etc.; however, agricultural cooperatives are still an important factor contributing to the success of the fields.

\section{3) Developing the number and structure of agricultural cooperatives}

In the period 2016-2019 (Table 3), there was a strong development of agricultural cooperatives in Thai Binh province. In 2016, there were only 320 agricultural cooperatives; in 2019, there were 487 agricultural cooperatives. Besides, the number of members also increased strongly from 447,987 members to 525,595 members in 2019. However, the revenue per member per year only underwent a slight growth from 70.6 million VND to 81.1 million VND per year. Similarly, the income and profit of cooperatives were calculated on a per-member basis. Thus, the agricultural cooperative in Thai Binh province has just developed in terms of the number of cooperatives and the number of cooperative members without the corresponding development of revenue and income of the cooperative.

\section{4) Operational efficiency of agricultural cooperatives}

Among the surveyed cooperatives, the general agricultural service cooperatives had the highest average profit of VND 164 million, followed by the livestock and fishery cooperatives (Table 4).

Currently, the rate of profit on cost of the cooperatives is low as compared to other forms of economic entities. As for fishery cooperatives, the highest profit/cost rate as compared to other groups was only almost $6 \%$ while that of general agricultural service cooperatives wass $3 \%$ and that of livestock cooperatives farming was $4.7 \%$. The average profit/cost rate of businesses was normally $25 \%$ - 
Table 3. Current status of cooperatives in Thai Binh province.

\begin{tabular}{|c|c|c|c|c|}
\hline \multirow{2}{*}{ Criteria } & \multicolumn{4}{|c|}{ Year } \\
\hline & 2016 & 2017 & 2018 & 2019 \\
\hline $\begin{array}{l}\text { Total number of agricultural cooperatives } \\
\text { (cooperatives) }\end{array}$ & 320 & 329 & 420 & 487 \\
\hline Number of cooperative members (members) & 447,987 & 468,720 & 500,210 & 525,595 \\
\hline Average revenue per cooperative (million VND) & 1003 & 1124 & 1192 & 1209 \\
\hline Average profit per cooperative (million VND) & 70.6 & 76.1 & 79.2 & 81.1 \\
\hline $\begin{array}{l}\text { Average income of a cooperative member per year } \\
\text { (million VND) }\end{array}$ & 20.1 & 20.7 & 21.3 & 22.9 \\
\hline
\end{tabular}

Source: Compilation from survey data, 2019.

Table 4. Profits of cooperatives in Thai Binh province (Unit: thousand VND).

\begin{tabular}{ccccc}
\hline Types of cooperatives & \multicolumn{5}{c}{ Profit } \\
\hline Agricultural cooperatives & 2016 & 2017 & 2018 & 2019 \\
\hline Aquacultural cooperatives & 164,509 & 165,102 & 166,709 & 172,091 \\
Animal production cooperatives & 61,176 & 42,237 & 43,210 & 44,345 \\
\hline
\end{tabular}

Source: Survey data, 2019. Exchange rate: 1 USD $=23,500$ VND.

$45 \%$. There need to be changes in production and business strategies, as well as technical advances to reduce costs, thereby helping to increase profit margins (Table 5).

The average income of a regular employee in cooperatives in 2016 reached 25 - 50 million VND/year. This is not a high level of income, but for agricultural workers, an average income.

\subsubsection{Cooperatives Engaged in the Development of Agricultural Production of the Province \\ 1) In cultivation}

The total cultivated area of the province in 2019 was 226,326 ha (Table 6); in which rice cultivation area was 159,280 ha; the variety structure and cultivation methods have positive changes in both spring and summer-autumn crops, the direct sowing area accounted for $33.5 \%$ of the total cultivated area. The area of rice cultivation tends to decrease, while the area of winter crops tends to increase. The planning, forecasting and guidance of pest control, caring and protection of crops are highly effective, especially the guidance of coping with the historical long cold spell in late January 2019 and the response to the storm No. 1. Therefore, rice harvesting in both seasons was great, the yield was estimated at 131.71 quintals/ha.

Winter crops continue to be developed sustainably, with local advantage crops being expanded, such as potatoes, peppers, melons of all kinds, and zucchini, etc. 
Table 5. Operating efficiency of the cooperatives in the study areas in 2019 (Unit: times).

\begin{tabular}{ccc}
\hline Types of cooperatives & Revenue/cost & Profit/cost \\
\hline Animal production & 1.05 & 0.047 \\
Aquaculture & 1.05 & 0.06 \\
Agriculture & 1.05 & 0.03 \\
\hline
\end{tabular}

Table 6. Structure of cultivated areas of the agricultural cooperatives (Unit: ha).

\begin{tabular}{|c|c|c|c|c|c|}
\hline \multirow{2}{*}{\multicolumn{2}{|c|}{ Crop structure }} & \multicolumn{4}{|c|}{ Area } \\
\hline & & 2016 & 2017 & 2018 & 2019 \\
\hline & Total area & 225,148 & 226,324 & 226,324 & 226,326 \\
\hline - & Rice area & 160,061 & 160,096 & 161,254 & 159,280 \\
\hline - & Winter crops & 34,711 & 35,701 & 36,290 & 38,902 \\
\hline- & Vegetables & 30,376 & 30,527 & 28,780 & 28,144 \\
\hline
\end{tabular}

Source: Compilation from survey data, 2019.

with an area of 38,902 ha. Cultivation areas of spring, summer and summer-autumn crops reach $28,144 \mathrm{ha}$, and the structure of vegetables and other crops has shifted towards development.

The program of large fields continues to be maintained and expanded by farmers, contributing to the improvement of commodity production; in 2019, the whole province had 262 fields with a total area of 12,164 ha, an increase of 85 fields as compared to 2015; in which in the spring crop season, there were 125 large fields with the area of 6210 ha, the number of large fields with the contract of product consumption was 84 fields, with the area of 4728 ha; in the autumn and winter crops, there were 137 fields with an area of 5954 ha, the number of fields with consumption contract was 78 fields with 3000 ha.

Many organizations and individuals accumulate agricultural land to convert to commodity production. In 2016, the whole province had 730.2 ha of cultivated land area, initially bringing about higher economic efficiency than normal production.

Some specific commodity producing areas have been established such as the chili production area in Quynh Phu, vegetables and melon production areas for exporting in Thai Thuy, Hung Ha; potato production areas in Thai Binh city, Dong Hung, Quynh Phu, Tien Hai, Kien Xuong, Vu Thu; and pumpkin production areas in Hung Ha, Quynh Phu, Thai Thuy, Vu Thu, Dong Hung. These production areas may be a premise for the development of specialized cultivation areas for large-scale commodity production of Thai Binh province in the near future.

The level of intensive farming in the household members of the cooperatives can be said to reach the highest level in the Red River Delta, thereby making the most of the area, using the crop-growing rotation formulas to increase the harvest value per unit area. For example, increasing the area for growing summer 
and winter crops on two rice crops land, using regenerated rice cultivation methods, both reducing costs and having land fund to grow high-value crops such as chili and vegetables, etc. The number of rotation of arable land in some places reached 4 - 5 cycles/year.

Direct seeding techniques by using improved, large-narrow row seeding tools, planting potatoes with a minimum tillage method and the technique of using fertilizers for crop cultivation, especially for rice, have been widely applied. The rate of mechanization of sowing in the province reached $34 \%$, with harvesting machines from $40 \%$ - 60\%; land preparation at $90 \%$ and $100 \%$ in milling and plucking rice. This rate is higher than the average of Vietnam, especially as compared to the Red River Delta provinces.

Trong Quan commune has provided great advices for consolidating and concentrating agricultural land plots, constructing inland transport and irrigation systems, advising the commune's local authorities in the construction of production projects which are suitable with local conditions, characteristics and land resources; planning of concentrated commodity production areas such as 50.27-ha model field, with the formula of 3-crop rotations per year, spring rice, winter rice, winter-autumn potatoes for the cultivation of DS1 rice variety (Japanese rice variety) sold freshly after harvesting with an average yield of 14.8 tons/ha/year. The winter crop of SoLaRa potato hadan average yield of 15.3 tons/ha, bringing high economic value of 192.6 million $\mathrm{VND} / \mathrm{ha}$, the officials and people of localities in Thai Binh province and from other provinces have visited Trong Quan commune's model fields to learn and gain experiences to apply in their own production, in addition, the cooperatives performed well in joint ventures and cooperated with others to provide seed, guidance and transfer science and technology and product consumption with domestic and foreign companies and enterprises in Thai Binh province and other provinces.

Agricultural cooperative of Nguyen commune, $\mathrm{Vu}$ Thu district built a 50-hectare rice field to produce rice seeds, and built a potato seed production area to serve two cold storages and expand the winter crop area. Infrastructure, especially the rural roads system, has been basically built, people's lives have been improved.

The average income per person in the whole commune was 22.8 million $\mathrm{VND} /$ person/year.

\section{2) In aquaculture production}

The total aquaculture area in 2019 was 15,987 ha (Table 7); in which, the clam farming area reached 3009 ha; the shrimp farming area reached 3198 ha, an increase of 130 ha as compared to 2018; the area of freshwater fish farming reached $9780 \mathrm{ha}$. In 2019, the province focused on investing, developing and expanding cage fish farming in the river, the current total number of cages are 493 cages, in which the number of real cages is 484 cages, the objects of farming include: Red snapper, Lang fish, grass carp, and carp, etc. The cooperative members actively acquire farming techniques according to GAP, focusing on developing valuable farming objects such as tiger fish, grouper, and blue crabs, etc. 
Table 7. Aquaculture cultivation área structure of agricultural cooperatives (Unit: ha).

\begin{tabular}{ccccc}
\hline \multirow{2}{*}{$\begin{array}{c}\text { Aquaculture cultivation area } \\
\text { structure }\end{array}$} & \multicolumn{4}{c}{ Area } \\
\cline { 2 - 5 } & 2016 & 2017 & 2018 & 2019 \\
\hline Total area & 14,591 & 14,592 & 14,689 & 15,987 \\
- Clam farming area & 2946 & 2948 & 3002 & 3009 \\
- Shrimp farming area & 2918 & 3087 & 3068 & 3198 \\
- Fresh-water fish farming area & 8257 & 8557 & 8619 & 9780 \\
\hline
\end{tabular}

Source: Compilation from survey data, 2019.

Aquaculture production yield was estimated at 198,737 tons, an increase of $8.62 \%$ as compared to 2018 .

A typical example of the province's aquaculture cooperatives is Hong Tien Fisheries Production-Service Cooperative, located in Hong Tien Commune, Kien Xuong District, Kien Xuong.

Hong Tien Commune is a coastal area of the Red River with many lakes and rivers. Especially due to its close proximity to the Red River, this is a brackish water area favorable for the development of freshwater and brackish water aquaculture. With 90.6 ha of water surface area, there are 47 households participating in the cooperative, on average, each household has a production area of over 1 ha, which is eligible to develop farm and farm economy, with 210 regular employees. In 2016, on average, the commodity value was 200 - 250 million $\mathrm{VND} /$ ha. Every year, cooperative members also exploited, raised and processed 2000 - 3000 liters of Vietnamese crab sauce, sold for 120,000 VND/liter and 700 - 800 liters of Ruoi sauce sold at the price of 450,000 VND/liter. The total value of the cooperative's aquatic product exploitation is VND 7 - 8 billion/year.

Other agricultural cooperatives, including Nam Cuong commune cooperative (Tien Hai), have also successfully converted 105 ha of low-yield rice cultivation into aquaculture, out of a total of 372.3 ha and 13 ha in off-shore áreas, applying new scientific and technological advances in breeding clams and making use of the available food source of local donor to raise black carp for an income of 300 350 million VND/ha.

\section{3) In animal production}

For collective economic activities, there are currently 02 livestock production cooperatives in the province (Table 8). Collaborative groups and teams have also appeared (mainly under the LIFSAP project, establishing 52 good animal husbandry practice groups according to VietGAHP standards and 9 animal husbandry cooperation groups).

In terms of production organization, domestic pig and $\mathrm{F} 1$ pigs tended to decrease, are being replaced by high-yield F2, F3 pigs and super lean pigs. Hybrid Ri chicken accounts for a large proportion in the total chicken flock. Industrial chickens are mainly raised or processed at household farms. The Sind crossbred cow has an increasing proportion, in 2000 only accounted for $20.7 \%$ of the total herd, by 2013 accounted for $43.9 \%$ of the total. Industrial feed for livestock is 
Table 8. Animal production structure of the agricultural cooperatives (Unit: heads).

\begin{tabular}{lcccc}
\hline \multirow{2}{*}{$\begin{array}{c}\text { Animal production } \\
\text { structure }\end{array}$} & \multicolumn{4}{c}{ Quantity } \\
\cline { 2 - 5 } & $\mathbf{2 0 1 6}$ & $\mathbf{2 0 1 7}$ & $\mathbf{2 0 1 8}$ & $\mathbf{2 0 1 9}$ \\
\hline Livestock population & $1,018,234$ & $1,022,068$ & $1,048,093$ & 500,568 \\
- Porkers & 832,678 & 868,345 & 851,631 & 328,798 \\
- Sows & 185,556 & 153,723 & 195,077 & 171,770 \\
- Poultry & $11,980,000$ & $12,168,000$ & $12,208,000$ & $13,567,000$ \\
- Cattle & 47,903 & 48,002 & 48,431 & 49,868 \\
\hline
\end{tabular}

Source: Compilation from survey data, 2019.

commonly used on farm households and on farms. There are about 100 animal feed production units and 850 animal feed shops in the province, forming level 1,2 and 3 agents.

Livestock production remains relatively stable any dangerous diseasees in cattle and poultry. In 2018, the total number of pigs was 1,048,093 heads (including 851,631 porkers and 195,077 sows); $12,208,000$ poultry and 48,431 cattle. Total meat output reached 253,742 tons, up by $4.2 \%$ as compared to 2015 . The selling price of livestock products in 2016 was stable; the breed structure has undergone many positive changes, foreign pig breeds and exotic crossbred pigs increased significantly in most localities in the province. However, in 2019, because of the African swine cholera epidemic, the total herd of pigs declined by about $50 \%$ to 500,568 heads, the issue of re-breeding poses an urgent need in 2020 and the following years to reduce pork prices in the market, meeting the needs of consumers.

Animal production thrived in the direction of large-scale farms, family farms continued to grow, and small-scale animal husbandry reduced rapidly. As of November 2016, the whole province had a total of 744 breeding farms, an increase of 16 farms as compared to 2015. The province's breeding cooperatives were established when exotic pigs develop wildly. This was a new field, so farmers had the need to learn about breeds, feed, veterinary medicine, breeding facilities and consumption markets, so livestock cooperatives were born at this time such as Viet Cuong Livestock cooperative in Dong Cuong Commune (Dong Hung District) and Thai Binh Agricultural Products Trading Cooperative (founded on August 30, 2014 under the business license No. 0807000002 issued by the Department of Planning and Investment on August 8, 2005, based in Thai Binh Breeding Joint Stock Company), these cooperatives were established to meet the actual needs mentioned above, such as: Cooperatives actively invite technical staff to train members, actively supply advancing materials or unsecuredly supplying materials and breeds to cooperative members and signing output contracts or providing information for cooperative members for selling their products. There are also the BAN MAI BIO Organic Breeding Cooperative (in Thai Hong Commune, Thai Thuy district), Thai Binh Organic Breeding Coop- 
erative (Certificate of Cooperative Registration No. 0807A00029 dated September 22, 2016 issued by the Thai Binh Department of Finance, Planning) with the head office in Tran Hien ward, Thai Binh city. These cooperatives connect their members, processing animal feed and semi-process, preserve products and selling them on their own.

Nine animal husbandry co-operative groups supported by the project were also quite effective, the members joined together to buy feed in bulk, so the buying price was low, supporting each other in breeding techniques and supplying seedlings, etc. such as Lien Giang (Dong Hung), Bach Thuan (Vu Thu), and Dong Tien (Quynh Phu). These are the premise cooperative groups for the formation of new livestock cooperatives.

\section{4) Agricultural trade}

Trade of agricultural cooperatives is carried out in two forms: selling products through affiliate and retail contracts (Table 9):

Currently, the province has a total of 210 cooperatives participating in the linkages for production and consumption of products for member households with 20 enterprises from inside and outside the province. The total cultivated area having product consumption contracts in 2018 was 9766 ha out of 226,324 ha $(4.32 \%)$ of the total cultivated land area of the whole year in the province. Of the total 210 cooperatives participating in the linkages, only about $35 \%$ of the cooperatives are sustainable, stable and effective, the rest (65\%) of the links are unsustainable, having low efficiency, some cooperatives are even unable to purchase products to resell to enterprises under signed contracts.

The average area with product consumption linkages per cooperative is 46.5 ha; However, the level of linkages among cooperatives is greatly different, some cooperatives only have 20 - 30 hectares with linkages, but there are also many cooperatives with very large areas of 200 - 350 hectares, accounting for $40 \%$ $50 \%$ of the total cultivated area of the commune.

The implementation of affiliate contracts: Currently, the actual purchase volume of enterprises only reaches an average of $60 \%$ of the volume of signed contracts; in

Table 9. Participation of agricultural cooperatives with linkages (participating in affiliate and retail contacts). (Unit: \%)

\begin{tabular}{lcccc}
\hline \multirow{2}{*}{ Criteria } & \multicolumn{4}{c}{ Year } \\
\cline { 2 - 5 } & 2016 & 2017 & $\mathbf{2 0 1 8}$ & 2019 \\
\hline $\begin{array}{l}\text { Total number of cooperatives with linkages } \\
\text { - Total number of cooperatives with }\end{array}$ & 180 & 189 & 190 & 210 \\
$\quad$ sustainable linkages & 63 & 67 & 68 & 75 \\
- Total number of cooperatives with & 117 & 122 & 122 & 135 \\
$\quad \begin{array}{l}\text { unsustainable linkages } \\
\text { - Average area with linkages (ha) }\end{array}$ & 30.5 & 33.6 & 38.7 & 46.5 \\
- Average yied with linkages & 40 & 46 & 55 & 60 \\
\hline
\end{tabular}

Source: Compilation from survey data, 2019. 
which the highest contract performance rate is the production of rice seeds, the average purchase output reaches $90 \%$ of the contracted output; regarding the implementation of high quality rice contracts, Japanese rice reaches an average of only $40 \%-50 \%$, mainly because households keep some of the harvest for household consumption; contract performance of crops reaches $45 \%-55 \%$ as compared to the signed contract because many households still sell a part of the production to outside traders.

In the linkages, cooperatives act as intermediaries to propagandize and mobilize member households to join the linkages, being the legal entity representing member households to sign product consumption contracts and to coordinate with businesses in instructing the production technology process for member households, and organizing the purchase of products from the member households to sell to businesses under the signed contracts. The linkage will meet the harmonious interests of three actors (Enterprises - Cooperatives - Households), specifically: For member households, productivity increases by $5 \%-10 \%$, prices increase by $10 \%-15 \%$, cost reduces by $5 \%-10 \%$ as compared to conventional production. For cooperatives, the benefits gained from the linkages are the acquisition of new scientific progress, the production direction is concentrated in a synchronized manner according to the standard process, the discount obtained from the signed output consumed for business, from 150 to $300 \mathrm{VND} / \mathrm{kg}$. For businesses, it will help to create stable material areas with uniform quality, thereby building a brand name on the typical market such as BC15, TBR225 rice seeds, high-quality Bac Thom 7 aromatic rice, T10 aromatic rice, and N97 aromatic rice, etc.

Regarding the consumption of products, cattle and poultry meat products are only sold at markets, small consumption points in localities in the province and a small part of products through preliminary processing for consumption in other provinces. The consumption through supermarkets of meat and poultry products is very limited.

About $30 \%$ to $40 \%$ of Thai Binh's livestock products were slaughtered and consumed in the province, the rest was sold to the outside of the province by traders in the form of live cattle and poultry. In addition to cattle and poultry products in general, Thai Binh also has the largest supply of piglets in the country with a total of $700-800$ thousand pigs/year, with an average output of 6000 tons/year. BAN MAI BIO Organic Breeding Cooperative has opened its stores in Thai Binh City and Hanoi City.

During the three years from 2017 to 2019, Thai Binh Agricultural Foodstuffs Consumption Cooperative has helped members of agricultural cooperatives selling 4130 Mong Cai breeding pigs at the weight of 25 - $30 \mathrm{~kg}, 3649$ F1 hybrid pigs with the average weight of $30 \mathrm{~kg}, 85$ buffaloes with the average weight of 180 $\mathrm{kg}$, and 294 crossbred cows, and supplied them with 1050 tons of synthetic feed, contributing greatly to the growth of Thai Binh's livestock industry.

5) Agricultural services provision 
The majority of agricultural cooperatives in the province carry out service activities for member households, from compulsory services formed from subsidy period such as irrigation, science and technology services to business service activities that compete with other economic sectors such as input service, product consumption service, cold storage, land preparation, internal credit, environmental sanitation rural areas, clean water, etc. (Table 10). In general, cooperatives that perform many services are cooperatives with good operational capacity, trusted by the member households to use harmonious services. Benefits between cooperatives and member households.

As the economy develops and people's lives are improved, there is an issue which is the environment affected by life waste. Grasping the needs of cooperative members and the local residents, the cooperative has launched waste collection environment services since 2012. In the period of 2017-2019, environmental services have been provided in an appropriate manner, therefore being highly supported by the provincial residents. That helps to minimize waste dumping into rivers, ditches and roads, limiting environmental pollution in the locality. The team of workers providing this service consists of 5 people who collecting garbage once every 2 days at the beginning of alleys, bringing them to the concentrated landfills. The fee for this service is $2000 \mathrm{VND} /$ person/month, collected every 6 months.

6) The conversion of agricultural cooperatives in the province

The conversion of agricultural cooperatives in accordance with the Law on Cooperatives in 2012 is the trend of most agricultural cooperatives in Thai Binh province, the cooperative conversion results mark the development of cooperatives in the agricultural sector in Thai Binh.

a) Main results and general evaluation on the quality of the conversion

The percentage of cooperatives completing the coversion procedures was high, at $72.03 \%$, but there was still $11.43 \%$ of cooperatives that have not carried out the conversion procedures yet, the number of weak cooperatives that cannot be converted and need to be dissolved was $4.92 \%$ (Table 11). Therefore, the

Table 10. Types of services provided by agricultural cooperatives (Unit: \%).

\begin{tabular}{lcccc}
\hline \multicolumn{1}{c}{ Types of services } & \multicolumn{3}{c}{ Year } \\
\cline { 2 - 4 } & 2016 & 2017 & 2018 & 2019 \\
\hline - Irrigation services & 100 & 100 & 100 & 100 \\
- Science and technology services & 80 & 85 & 86 & 90 \\
- Input supply services & 90 & 91 & 94 & 96 \\
- Product consumption service & 51 & 52 & 55 & 60 \\
- Cold storage services & 40 & 43 & 47 & 100 \\
- Land preparation services & 100 & 100 & 100 & 68 \\
\hline
\end{tabular}

Source: Compilation from survey data, 2019. 
Table 11. Main results of the conversion of agricultural cooperatives since the 2012 cooperative law started to take effect.

\begin{tabular}{lc}
\hline \multicolumn{1}{c}{ Criteria } & Percentage (\%) \\
\hline $\begin{array}{l}\text { Cooperatives that finish conversion } \\
\begin{array}{l}\text { Cooperatives that have submitted re-registration/have notified changes in the } \\
\text { content of cooperative business registration }\end{array}\end{array}$ & 72.03 \\
$\begin{array}{l}\text { Cooperatives that are conducting the conversion procedures } \\
\text { Cooperatives that have not conducted the conversion procedures }\end{array}$ & 11.62 \\
Weak cooperatives that cannot be converted, need to be dissolved & 11.43 \\
General evaluation on the coversion quality & 4.92 \\
The conversion is intrinsic & 38.17 \\
The conversion is extrinsic & 61.83 \\
\hline
\end{tabular}

Source: Compilation from survey data, 2019.

continuation of providing supports to transform cooperatives under the 2012 Cooperative Law is still an urgent task for local authorities.

2) Advantages and difficulties that cooperatives have during the conversion process

From Table 12, it can be seen that most of the administrative procedures to support the cooperative cooperatives accounted for a high rate of over $85 \%$ such as the documents providing guidance, directions and management issued by the government. However, important factors in maintaining, developing and organizing the operation of cooperatives have a relatively high rate of obstacles such as contributed capital of members, cooperative-provided services, facilities, scale and operation methods of the cooperatives, distribution of profits based on the level of use of products and services of cooperatives, and the rate of setting up of funds of cooperatives. These are the severe issues, requiring efforts of all members of the cooperatives and members of the Cooperative Management Board to organize activities and develop cooperatives in the new period.

\subsection{Solutions for the Development of Agricultural Cooperatives in Thai Binh Province}

\subsubsection{Solutions Relating to the Propaganda and Awareness Raising in Collective Economy}

Enhance the thorough understanding of the true and complete awareness of the nature of cooperative economy, of new-type cooperatives under the 2012 Cooperative Law and documents guiding the implementation of policies and policies to support development. developing cooperative economy for Party committees and local governments, promoting synchronous coordination between sectors and grassroots levels; In assessing the effectiveness of cooperative economy, it must be based on the comprehensive view of economy - politics - society, both the effectiveness of cooperatives and members' effectiveness, avoiding one-sidedness, leading to misunderstanding about Cooperative economy. Propagating, disseminating 
Table 12. Advantages and obstacles that cooperatives have during the conversion process.

\begin{tabular}{|c|c|c|c|c|c|}
\hline Criteria & Advantages & Percentage (\%) & Difficulties & Percentage (\%) & Total \\
\hline Contributed capital of members & 4 & 16.67 & 20 & 83.33 & 24 \\
\hline $\begin{array}{l}\text { Members' requirements for using products and services provided by } \\
\text { cooperatives }\end{array}$ & 6 & 25.00 & 18 & 75.00 & 24 \\
\hline $\begin{array}{l}\text { The maximum rate of supplying products and services of the } \\
\text { cooperative to outside individuals or organizations }\end{array}$ & 5 & 20.83 & 19 & 79.17 & 24 \\
\hline Financial situation of the cooperative & 6 & 25.00 & 18 & 75.00 & 24 \\
\hline Infrastructure of the cooperative & 7 & 29.17 & 17 & 70.83 & 24 \\
\hline $\begin{array}{l}\text { Organization of the management and executive apparatus of the } \\
\text { cooperative }\end{array}$ & 10 & 41.67 & 14 & 58.33 & 24 \\
\hline Scale and mode of operation of the cooperative & 7 & 29.17 & 17 & 70.83 & 24 \\
\hline $\begin{array}{l}\text { Distribution of profits based on the uses of products and services of } \\
\text { the cooperative }\end{array}$ & 5 & 20.83 & 19 & 79.17 & 24 \\
\hline Rate of setting up cooperative funds & 3 & 12.50 & 21 & 87.50 & 24 \\
\hline $\begin{array}{l}\text { Qualification, capacity to meet operational requirements and } \\
\text { stability of the key staff of the cooperative }\end{array}$ & 3 & 12.50 & 21 & 87.50 & 24 \\
\hline Guiding documents of different level & 18 & 75.00 & 6 & 25.00 & 24 \\
\hline Prerequisite procedures to convert and/or re-register cooperatives & 19 & 79.17 & 5 & 20.83 & 24 \\
\hline Direction and guidance of the provincial government & 20 & 83.33 & 4 & 16.67 & 24 \\
\hline Direction and administration of the district authorities & 20 & 83.33 & 4 & 16.67 & 24 \\
\hline Implementation at the communal authorities & 20 & 83.33 & 4 & 16.67 & 24 \\
\hline $\begin{array}{l}\text { Awareness of cooperative members about the conversion and } \\
\text { re-registration of cooperatives }\end{array}$ & 3 & 12.50 & 21 & 87.50 & 24 \\
\hline
\end{tabular}

Source: Compilation from survey data, 2019.

and thoroughly grasping the contents of the Central Resolution 5, Session IX on the continuation of renewal, development and raising the operational efficiency of the collective economy and the 2012 Cooperative Law, especially on characteristics of the new type of cooperative.

Promote the propaganda to members of the cooperatives and the local people about the 2012 Law on Cooperatives, Decree No. 193/ND-CP of the Government, Decision No. 2261/QD-TTg dated December 15, 2014 by the Prime Minister, the Plan for renewing and developing forms of cooperative economic organizations in agriculture of the Ministry of Agriculture and Rural Development and other guidelines and policies of the Central and the provincial governments for the economy cooperation and development of production and business in the field of agriculture.

Focus on propagating and disseminating models of cooperatives, cooperative groups which operate effectively, and cooperatives taking part in product consumption cooperation, participating in land accumulation to create a change in awareness of officials and people about the role of cooperatives and cooperative groups in developing agricultural production and implementing land accumula- 
tion in the locality.

\subsubsection{Solutions Relating to the Market and Connection between Cooperatives and Economic Sectors}

Create and develop product brands for cooperatives, and, at the same time, select specific products that match the cooperative's strengths, thereby designing beautiful designs, creating differences and high safety for the products.

Implement policies to support the development of large fields; Select a number of agricultural products with competitive advantages; Focuse on investment, organizing production in association with consumption markets, bringing high economic efficiency to implement restructuring.

Strengthen market management, quality control and traceability of agricultural and food products.

\subsubsection{Solutions Relating to Supporting Mechanism and Policies for the Cooperatives}

Agricultural cooperatives are the community organizations of farmers in a spirit of voluntariness, self-reliance, self-help, self-responsibility, being both economic and social entities. Therefore, the government should have policies to support and encourage the development of agricultural cooperatives. The policies should be strong enough, sufficient, suitable to the organization and operation conditions of the cooperative, and easy to implement; the policies must be uniformly implemented throughout the province.

1) Policies on finance and credit

Reforming the credit policy towards facilitating agricultural cooperatives to access credit capital more easily through determining conditions and the level of non-mortgage lending to agricultural cooperatives; unsecured lending mechanism through the production and business efficiency of the agricultural cooperative in one to two fiscal years as a healthy, effective and reputable main vessel in production and business, or already borrowed capital but pay debt on time; strengthening the form of unsecured lending by mass organizations and communal authorities, etc.

Regarding tax policies for agricultural cooperatives in the current period, the government should exempt corporate income tax on income from service activities that agricultural cooperatives directly provide to serve agricultural production of cooperative members such as supply of materials, processing, and product consumption, etc. in order to create favorable conditions for agricultural cooperatives to accumulate capital for reinvestment.

\section{2) Land policies}

Speeding up the allocation of land and the issuance of "certificates of land ownership, ownership of houses and other properties associated with the land" to agricultural cooperatives.

Expanding the level, duration and objects of agricultural cooperatives enjoying land rent incentives, and at the same time having strict management mechanisms to avoid other wasteful and negative land uses. 


\section{3) Supporting policies for the transfer of scientific and technological advances}

Increasing investment in training and fostering scientific staff serving the production and business fields and in infrastructure for research. Enhancing the training and retraining of officers engaged in the application, propagation and dissemination of scientific and technological advances in service of production and business fields, especially agricultural cooperative officers, so that they are really a bridge between science and technology organizations and people directly doing business.

Increasing investment in scientific and technological research and application in production and business fields, especially in agricultural production (from seeding stage to cultivation, husbandry, harvesting, processing, and preserving methods).

\section{4) Market policies}

Building information systems, market forecasts of inputs and outputs of production and business sectors to ensure market information delivered to producers and businesses in a timely, accurately and fully. Developing the network of rural markets and exhibition centers to introduce commodity products, especially agricultural commodity products.

Increasing support and creating conditions for agricultural cooperatives to participate in trade promotion programs, specifically providing supports for cooperatives to participate in exhibitions, trade fairs; providing supports in brand building and brand promotion; and providing supports in finding business partners and expanding markets, etc.

\section{5) Policies on officials and labourers}

Promote training and retraining officers of agricultural cooperatives with professional knowledge. Accordingly, clearly assign and decentralize responsibilities and powers in training and fostering agricultural cooperatives between the provincial cooperative alliance, departments and localities in the province. The training and retraining of officials of agricultural cooperatives must be carried out according to the motto of frequent and continuous implementation, combining training and retraining, and prioritizing the training and retraining of key officials of agricultural cooperatives.

\subsubsection{Solutions Relating to the Strengthening of Government Management on Collective Economic Forms}

The formulation of strategies, plannings and plans for the development of agricultural cooperatives must thoroughly grasp the Communist Party and government's viewpoint which is the continuation of the innovation and development to improve collective economic efficiency in general and agricultural cooperatives in particular is aimed at getting rid of current weaknesses, achieving higher growth rates and greater efficiency in different areas. In order to achieve those goals and requirements, the agricultural cooperatives must obtain strong and fundamental changes and need to be oriented towards the following specific contents; 
The development of agricultural cooperatives is closely linked and serves the successful implementation of the country's socio-economic development guidelines and strategies. This is not only a requirement, but first and foremost, a basis for mobilizing resources for the innovation and development of agricultural cooperatives. And it must be considered as an important solution to successfully implement the provincial socio-economic development guidelines and strategies. The development of agricultural cooperatives and aims at meeting the economic, cultural and social needs of a large number of social classes and gathering, widely linking all types and economic organizations, paying special attention to workers and individual economic households.

The development of agricultural cooperatives also needs to be expanded and directed to a large number of population strata, social circles and a large number of people with demands to meet that demand.

Agricultural cooperatives development should be expanded into all fields of businesses that are needed.

It is of importance to develop a diversified agricultural cooperative model in form, developing from low to high, from providing production services and life services to member households and cooperative members to diversifying businesses and aiming at aggregate business production in agriculture.

\section{Conclusion}

The theory of cooperatives affirms the important and pivotal role of agricultural cooperatives in socio-economic development in rural areas. Practical practices of cooperatives in some countries around the world have also helped to prove that. In Thai Binh, there have been positive results in the development of cooperatives since 1960. The continuation of the development of cooperatives in the agricultural sector is not only necessary but also urgent in the process of implementing Resolution 26-NQ/TW, Resolution of the 7th Plenum of the Central Executive Committee of the $\mathrm{X}$ term on Tam Nong. As a result, the operational efficiency of the typical cooperative models in the province needs to be replicated. Some groups of urgent solutions to develop cooperatives in the agricultural sector of Thai Binh Province are as follows: 1) Group of solutions relating to propagating and raising awareness in collective economy; 2) Group of solutions relating to the markets and linkages between cooperatives and economic sectors; 3) Group of solutions relating to mechanisms and policies to support cooperatives; and 4) Group of solutions relating to the strengthening of national management of collective economic forms.

\section{Conflicts of Interest}

The authors declare no conflicts of interest regarding the publication of this paper.

\section{References}

An, S., \& Culas, R. (2015). Impact of Contract Farming with Farmer Organizations on 
Farmers' Income: A Case Study of Reasmey Stung Sen Agricultural Development Cooperative in Cambodia. Australasian Agribusiness Review, 23, 1-11.

Brătulescu, A.-M. (2017). Agricultural Cooperatives in Developing Agriculture in Romania and the European Union. MPRA Paper No. 85371.

Central Executive Committee of Vietnam (1955). Resolution of the 8th Meeting of the Central Committee of the Communist Party of Vietnam (Session II) in August 1955.

Dogarawa, D. (2005). The Role of Cooperative Societies in Economic Development. MPRA Paper, Germany: University Library of Munich.

Duong, P. B. (2015). Some Theoretical and Practical Issues about the Innovation and Development of Cooperatives in Vietnam Rural Areas. Economic Research, 449, 48-54.

Huang, Z., \& Liang, Q. (2018). Agricultural Organizations and the Role of Farmer Cooperatives in China Since 1978: Past and Future. China Agricultural Economic Review, 10, 48-64. https://doi.org/10.1108/CAER-10-2017-0189

Kogabayev, T. (2019). Development of Agricultural Cooperatives in Kazakhstan.

Lacuna-Richman, C., Gill, D. S., \& Murray, E. C. (1993). Cooperative and Rural Development: The Case of Dayap Credit Cooperative and Development Inc., Philippines. http://ageconsearch.umn.edu/record/232376/files/ualberta-projectreports-93-09.pdf

Mann, S. (2018). Agricultural Cooperation. In S. Mann (Ed.), Socioeconomics of Agriculture (pp. 65-85). Cham: Springer International Publishing. https://doi.org/10.1007/978-3-319-74141-3 4

MARD (2018). Situation Report on the Current Cooperative Law and Government Decrees in the Field of Agriculture. (In Vietnamese)

National Assembly of Vietnam (1996). Law on Cooperatives 1996. (In Vietnamese)

National Assembly of Vietnam (2003). Law on Cooperatives 2003. (In Vietnamese)

National Assembly of Vietnam (2012). Law on Cooperatives 2012. (In Vietnamese)

Nguyen, N. (2012). The Development of Cooperatives and the Role of Cooperatives for Social Security.

Sedik, D., \& Lerman, Z. (2015). Agricultural Cooperative Development in Kazakhstan and Ukraine. In A. Schmitz, \& W. H. Meyers (Eds.), Transition to Agricultural Market Economies: The Future of Kazakhstan, Russia and Ukraine (pp. 81-91). CABI. https://doi.org/10.1079/9781780645353.0081

Shcherbyna, S. V. (2014). Cooperative Association Development in Ukraine's Agricultural Sector of Economy. Management, 9, 170-178.

Song, N., Phuong, N., Cuong, H., Diep, N., Diep, D., Huyen, V., Huyen, V., Tiep, N., \& Trang, T. (2020) Vietnamese Agriculture before and after Opening Economy. Modern Economy, 11, 894-907. https://doi.org/10.4236/me.2020.114067

Sultan, T., \& Wolz, A. (2012). Agricultural Cooperative Development in China and Vietnam Since Decollectivisation: A Multi-Stakeholder Approach. Journal of Rural Cooperation, 40, 239-257.

Vieta, M., \& Lionais, D. (2015). The Cooperative Advantage for Community Development. Journal of Entrepreneurial and Organizational Diversity, 4, 1-10. https://doi.org/10.5947/jeod.2015.001

Vietnam's Government (2013). DECREE No. 193/2013/ND-CP Elaborating on Certain Articles of the Law on Cooperatives.

Vietnam's Government (2014). Decision No. 2261/QD-TTg on Approving the Program Support for Cooperative Development in the Period 2015-2020.

Vietnam's Government (2017). DECREE No. 107/2017/ND-CP Amendments and Sup- 
N. C. Tiep et al.

plements to Government's Decree No. 193/2013/ND-CP Dated November 21, 2013, Elaborating on Certain Articles of the Law on Cooperatives.

Wolz, A., \& Duong, P. B. (2010). The Transformation of Agricultural Producer Cooperatives-The Case of Vietnam. Journal of Rural Cooperation, 38, 117-133. 